\title{
STUDY OF SERUM LIPID PROFILE IN RENAL FAILURE PATIENTS ATTENDING NOBEL MEDICAL COLLEGE, BIRATNAGAR
}

\author{
Shrawan Kumar Yadav, Niraj Nepal and Dilliram Niroula
}

\begin{abstract}
Renal Failure is a condition in which the kidneys fail to remove metabolic end products from the blood \& regulate the fluid, electrolyte $\& \mathrm{p}^{\mathrm{H}}$ balance of extracellular fluids. The underlying causes may be renal disease, systemic disease or urinary tract disorder of non-renal origin. The present study is undertaken with the aim to study of serum lipid profile in renal failure patients attending Nobel Medical College, Biratnagar from February 2012 to February 2013. To assess serum lipid profile, albumin \& $\mathrm{C}$ - reactive protein in renal failure patients on peritoneal $\&$ hemodialysis, it included 70 patients, 31 were males $\& 39$ were females $\&$ their age range from 21 to 80 years. The control groups were 35 , they were collected from medical staff \& relatives who were free from signs \& symptoms of renal disease, lipid disorders, diabetes mellitus \& hypertension. 19 were males \& 14 were females \& their age range from 22 to 66 years.
\end{abstract}

Key words: Renal failure, Lipid profile

\section{Introduction}

Renal failure refers to a condition where the kidneys lose their normal functionality, which may be due to various factors including infections, auto immune disease, diabetes, other endocrine disorders, cancer and toxic chemicals. It is characterized by the reduction in the excretory and regulatory functions of the kidney, it is the ninth leading cause of death in United States as well as most industrialized nation throughout the world. ${ }^{1}$

With the improvement in conservative management and dialysis, the life span of patients with chronic renal failure (CRF) has been increased. As the patient's survival has approached the 10 years, there is an increasing indication that accelerated atherosclerosis may remain a major un resolved problem threatening the longevity of CRF patients. ${ }^{2}$
Cardiovascular disease (CVD) is the leading cause of the death among patients with chronic and end stage renal disease (ESDR). ${ }^{3}$

There is growing evidence that cardiovascular damage begins as soon as the kidney loses functions and increases in severity during the progression of kidney disease. ${ }^{4}$

Dyslipidemia independently or in combination with elevated blood pressure, can cause deterioration in renal function. Abnormalities in lipid metabolism and dyslipedemia are known to contribute to glomerulosclerosis and are common in Renal disease. $^{5} \quad$ In addition post- transisplant dyslipidemias have been associated with an increased risk of ischemic heart disease and have been shown to increase risk of chronic rejection, altered graft function and mortality ${ }^{6}$ . The impact of lipid abnormalities on renal function has been evaluated in various 
studies $^{7}$. In these studies unfavorable iliporotein profiles interacted as risk factors for progressive renal decline. Abnormal lipid profiles start to appear soon after renal function begins to deteriorate ${ }^{8}$. Common characteristics of the lipid profile include an elevation of serum triglycerides, a decrease in the high-density lipoprotein (HDL) cholesterol, and some elevation in the lowdensity lipoprotein (LDL) cholesterol and marked oxidation of LDL cholesterol. All of which have been associated with increased atherosclerotic risk ${ }^{9}$.

Epidemiological studies have also suggested a role for hyperlipidemia in the progression of diabetic nephropathy ${ }^{10}$. Analyses and prevalence reports have estimated that about $45-50 \%$ of haemodialysis and peritoneal dialysis patients have lipid abnormalities (Essentials of pathophysiology 2006). With the implication of plasma lipids in the pathogenesis of atherosclerosis and ischemic heart disease, it becomes worldwide to study the behavior of various lipid fractions in CRF patients $^{11}$.

\section{Material and Methods \\ Patients and control group \\ Patients}

The collection of samples was conducted during the period from February 2012 to February 2013. Out of 80 patients participated in the study from Nobel Medical College, Biratnagar Nepal, ten patients were excluded from the study for having one of the following:-

- Thyroid disorder.

- Nephrotic syndrome.

- Primary hyperlipidemia.

- Liver dysfunction resulting from hepatitis, biliary obstruction or cirrhosis.

So, 70 patients remain for the study, 31 were males and 39 were females with female to male ratio (1.3:1) and their ages ranged from
21 to 80 years. The patient was diagnosed as renal failure for both sexes based on the history, clinical examination and taking renal function test (creatinine increased 3.0 times OR creatinine $>355 \mu$ mole or urine output below $0.3 \mathrm{ml} / \mathrm{kg}$ for 24 hours).

\section{Control Group}

The control groups consist of 35 subjects. They were collected from medical staff and relatives who were free from signs and symptoms of renal disease, lipid disorders, diabetes mellitus and hypertension, 19 were males and 14 were females, with male to female ratio (1.4:1) and their ages ranged from 22 to 66 years.

\section{Collection of Samples}

Ten milliliters of venous blood were drawn from each fasting patient (8-12 hours fasting). Slow aspiration of the venous blood sample via the needle of syringe to prevent hemolysis with tourniquet apply $15 \mathrm{~cm}$ above the cubital fossa. All the samples which were grossly hemolysed, were neglected and other samples were taken.

\section{Methods}

\begin{tabular}{|l|l|}
\hline Tests & Method \\
\hline Triglyceride & GPO method \\
\hline Total cholesterol & CHOD/PAP method \\
\hline Albumin kit & BCG Method \\
\hline $\begin{array}{l}\text { HDL } \\
\text { Cholesterol }\end{array}$ & $\begin{array}{l}\text { PEG precipitation } \\
\text { method }\end{array}$ \\
\hline Creatinine & Jaffe's method \\
\hline
\end{tabular}

\section{Results}

\section{Distribution of the enrolled patients}

The evaluation of the data of our patients indicated that the enrolled patients were distributed according to cause of disease, the associated disease with renal failure, type of dialysis, and the renal transplant. 


\section{Age:}

The age distribution in renal failure shows a peak level in the age between (50-60) years represented by 21 patients and the least was in the age group between (70-80) years represented by 5 patients.

Figure (1) the age distribution of renal failure patients.

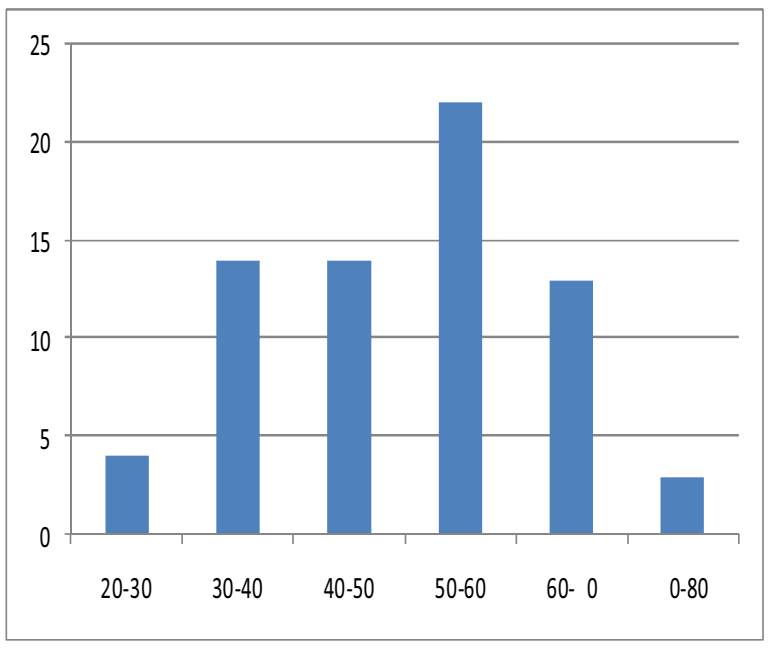

\section{Sex:}

In our study the enrolled patients were distributed according to sex into two groups; the female group $(58 \%)$ of the patients was found to be higher than the male group $(42 \%)$.

Figure (2) Variability of distribution of renal failure in different sex.

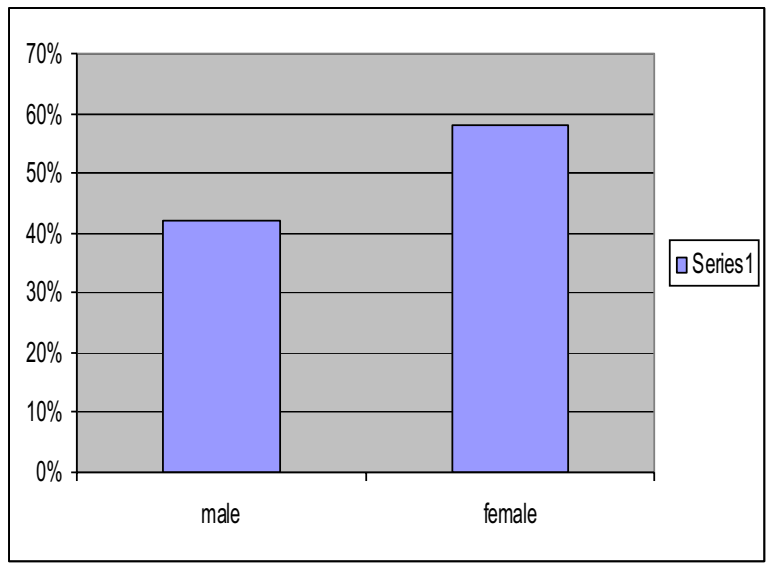

\section{Types of Dialysis:}

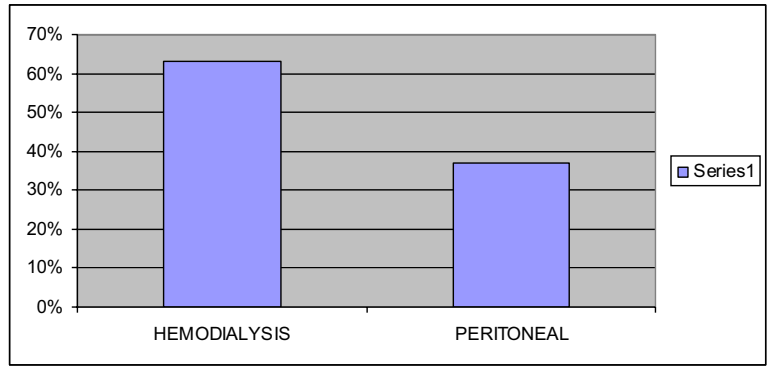

According to the type of dialysis (whether hemodialysis or peritoneal dialysis) the patients were divided into two groups, those undergoing hemodialysis were found to be higher than peritoneal dialysis.

\section{The cause of Renal Failure:}

Most of cases of renal failure was found to be of unknown etiology (45\%), the second most common one is stones $(22 \%), 5 \%$ associated with infection, 5\% were due to single kidney, 4\% for polycystic kidney, 4\% for post-partum hemorrhage, $1 \%$ for vesicoureteral reflux, $1 \%$ for obstructive, $1 \%$ for renal agenesis.

\section{The associated systemic disease:}

In this study it was found that the systemic diseases associated with our renal failure patients have the following consequences:

Hypertension (73\%), diabetes mellitus (12\%), rheumatoidarthritis $(8 \%)$, mental disorder (5\%), and (SLE) systemic lupus erythymatosus $(2 \%)$.

3-2. Measurement of serum lipid profile and albumin concentration in renal failure patients and control group.

The result demonstrated significant $(\mathrm{P}<.001)$ elevation in serum Cholesterol, Triglyceride, LDL- cholesterol, VLDL concentration in renal failure patients when compared with those of the control group, while HDL- cholesterol, Serum albumin concentration is significantly lower $(\mathrm{P}<.001)$ 
in renal failure patients when compared with those of the control group.

Table (3-1) Serum lipid profile and albumin concentration in renal failure patients and control group.

\begin{tabular}{|l|l|l|l|}
\hline $\begin{array}{l}\text { Serum lipid } \\
\text { profile }\end{array}$ & $\begin{array}{l}\text { Control } \\
\text { (Mean } \pm \text { SD) }\end{array}$ & $\begin{array}{l}\text { Patient } \\
\text { (Mean } \pm \text { SD) }\end{array}$ & $\begin{array}{l}\text { P- } \\
\text { value }\end{array}$ \\
\hline $\begin{array}{l}\text { Cholesterol } \\
(\mathrm{mg} / \mathrm{dl})\end{array}$ & $173.20 \pm 2.80$ & $\begin{array}{l}229.28 \\
58.61\end{array}$ & $\begin{array}{l}<0.00 \\
1\end{array}$ \\
\hline $\begin{array}{l}\text { Triglyceride } \\
(\mathrm{mg} / \mathrm{dl})\end{array}$ & $\begin{array}{l}173.11 \pm \\
23.38\end{array}$ & $\begin{array}{l}185.41 \pm \\
79.01\end{array}$ & $\begin{array}{l}<0.00 \\
1\end{array}$ \\
\hline $\begin{array}{l}\text { LDL } \\
\text { Cholesterol } \\
(\mathrm{mg} / \mathrm{dl})\end{array}$ & $93.36 \pm 26.25$ & $\begin{array}{l}150.99 \pm \\
57.87\end{array}$ & $\begin{array}{l}<0.00 \\
1\end{array}$ \\
\hline $\begin{array}{l}\mathrm{HDL}- \\
\text { cholesterol } \\
(\mathrm{mg} / \mathrm{dl})\end{array}$ & $52.45 \pm 9.49$ & $39.88 \pm 9.29$ & $<0.00$ \\
\hline $\begin{array}{l}\text { VLDL- } \\
\text { cholesterol } \\
(\mathrm{mg} / \mathrm{dl})\end{array}$ & $27.35 \pm 4.71$ & $37.01 \pm 15.85$ & 1 \\
\hline $\begin{array}{l}\text { Serum } \\
\text { albumin }(\mathrm{g} / \mathrm{dl})\end{array}$ & $4.49 \pm 0.96$ & $3.20 \pm 0.97$ & $<0.00$ \\
\hline
\end{tabular}

3-2 Effect of sex on serum lipid profile and albumin concentration in renal failure patients:

The statistical analysis demonstrated that there is no significant difference between male and female patients regarding their cholesterol, triglyceride, low density lipoprotein, high density lipoprotein, very low density lipoprotein, serum albumin levels.

Table (3-2) Effect of sex on serum lipid profile and albumin concentration in renal failure patients

\begin{tabular}{|l|l|l|l|}
\hline $\begin{array}{l}\text { Serum lipid } \\
\text { profile }\end{array}$ & $\begin{array}{c}\text { Male } \\
\text { (Mean } \pm \text { SD) }\end{array}$ & $\begin{array}{c}\text { Female } \\
\text { (Mean } \pm \text { SD) }\end{array}$ & \multicolumn{1}{c|}{$\begin{array}{c}\text { P- } \\
\text { value }\end{array}$} \\
\hline $\begin{array}{l}\text { Cholesterol } \\
(\mathrm{mg} / \mathrm{dl})\end{array}$ & $232.08 \pm 62.56$ & $227.05 \pm 56.00$ & $\mathrm{NS}$ \\
\hline $\begin{array}{l}\text { Triglyceride } \\
(\mathrm{mg} / \mathrm{dl})\end{array}$ & $165.77 \pm 80.44$ & $201.01 \pm 75.24$ & $\mathrm{NS}$ \\
\hline $\begin{array}{l}\text { LDL } \\
\text { Cholesterol } \\
(\mathrm{mg} / \mathrm{dl})\end{array}$ & $159.15 \pm 59.16$ & $144.51 \pm 56.74$ & $\mathrm{NS}$ \\
\hline $\begin{array}{l}\text { HDL- } \\
\text { cholesterol } \\
(\mathrm{mg} / \mathrm{dl})\end{array}$ & $38.88 \pm 9.31$ & $40.68 \pm 9.31$ & $\mathrm{NS}$ \\
\hline $\begin{array}{l}\text { VLDL- } \\
\text { cholesterol } \\
(\mathrm{mg} / \mathrm{dl})\end{array}$ & $33.08 \pm 16.10$ & $40.19 \pm 15.12$ & $\mathrm{NS}$ \\
\hline $\begin{array}{l}\text { Serum } \\
\text { albumin }(\mathrm{g} / \mathrm{dl})\end{array}$ & $3.91 \pm 0.69$ & $3.69 \pm 0.59$ & $\mathrm{NS}$ \\
\hline
\end{tabular}

\section{Discussion}

In this study it was found that the kidney failure was peaked in the age 50 to 60 years in contrast with other studies in western countries in which peak incidence is older than 75 years. It may be due to the reason that most of Nepali people suffer from diabetes mellitus or hypertension (which are the most common cause of chronic renal failure) have either poor compliance to the drugs or under controlled therapy. Limited medical services and delay medical consultation may be another cause for such incidence.

Regarding the patients gender it was found that female patients $(58 \%)$ is higher than male patients $(42 \%)$ with female to male ratio 1.3:1 unlike what have been reported in western studies in which annual incidence was twice as high in males than in females, this is probably attributed to that female patients presented in our study are in reproductive age group with more liability for urinary tract infection, post-partum hemorrhage (which represent $(4 \%)$ of cause of acute irreversible renal failure) .

In this study it was found that number of patients who were treated with hemodialysis $(63 \%)$ was higher than those treated with peritoneal dialysis (37\%), this is because of advantages of hemodialysis which has short dialysis period with frequent sessions.

Peritoneal dialysis was associated with much more complications like infection notably peritonitis, proteins loss in the dialysate fluid with subsequent post dialysis dyslipidemia. All these made hemodialysis superior to peritoneal dialysis.

Peritoneal dialysis was reserved for emergencies and when the patients with renal failure became stable they were shifted to 
hemodialysis, finally only the patients with absolute contraindications to hemodialysis will stay on peritoneal dialysis.

\section{4-1 Lipid Profiles}

Plasma triglyceride concentration was frequently elevated in patients with CRF. This Elevation is accompanied by increased plasma concentration and impaired clearance of VLDL, which is associated with the accumulation of atherogenic VLDL remnants, commonly known as IDL. Fasting hypetriglyceridemia is a well-known abnormality in chronic renal failure Patients of western population. In recent studies it has been found that Down regulation of skeletal muscle and adipose tissue LPL, hepatic lipase and VLDL receptor and of hepatic LRP is collectively responsible for hypertriglyceridemia, impaired clearance, and elevated plasma levels of VLDL, IDL, and chylomicron remnants. Hypertriglyceridemia is treated by restriction of carbohydrates and fat in the det, as well as with niacin, fibrates and statins, Niacin $\left(\mathrm{B}_{3}\right)$ which block breakdown of fats also lowers VLDL and consequently LDL. It comes with the added benefit of increasing High density lipoprotein, HDL.

Frequent elevation of plasma total cholesterol and LDL concentration in patients with CRF have been found, whereas in western studies total cholesterol and LDL are only occasionally elevated, this is may be due to one of the following:

Most of our patients in the study have poor compliance to diet control and medications for hypercholesterolemia.

In many instances development and progression of renal insufficiency are accompanied by heavy proteinuria, leading to superimposition of nephritic dyslipidemia on CRF- induced lipid disorders. In these circumstances, plasma total cholesterol and LDL cholesterol concentration are frequently elevated because heavy proteinuria alone or in combination with chronic renal insufficiency results in acquired LDL receptor deficiency, which plays a central role in the genesis of the associated hypercholesterolemia.

It is of note that losses of proteins through the peritoneum in ESRD patients treated with chronic peritoneal dialysis stimulate nephrotic syndrome and lead to a lipid profile that frequently includes hypercholesterolemia and an elevated LDL level. The effects of peritoneal losses of protein on lipid metabolism in peritoneal dialysis patients are accompanied by peritoneal absorption of large quantities of glucose. The ultimate hypoproteinemia together with hyperglycemia with accentuate the hypertriglyceridemia.

\section{References}

1. Meyer TW and Hostetter T.H. Uremia. N Engl J Med. 2007 ; 357(13):1316

2. Linder;A; Charra; B; Sherrard; D. J. and Scribner. J. Med. 1974; 290:697

3. Foley RN and Parfrey PS; Clinical epidemiology of cardiovascular disease in chronic renal disease. 1998 Nov;32(5 Suppl 3):S112-9

4. Jungers P; Massy $\mathbf{Z}$ N. Transplant. 1997; 12:2597-602.

5. Moorhead JF; Chan MK; EL-Nahas M; et al. Lipid nephrotoxicity in chronic progressive glomerular and tubule intersticial disease.1982; Lancet 2: 1309-11. .

6. Massy ZA; Kasiske BL. Post-transplant hyperlipidemia: mechanisms and management. J Am Soc Nephrol 1996; 7: 971-7.

7. Schaeffner ES and Kurth T. Cholesterol and the risk of renal dysfunction in apparently healthy men. 2003 Aug;14(8):2084-91

8. Freedman DS and Otvos JD. Relation of lipoprotein subclasses as measured by proton nuclear magnetic resonance spectroscopy to coronary artery disease. $1998 \mathrm{Jul} ; 18(7): 1046-53$

9. Krolewski AS, Warram JH, Christlieb AR. Hypercholesterolemia- a determinant of Renal function loss and deaths in IDDM patients with nephropathy. 1994 Kidney Int 45: S 125-31. 
10. Kasiske BL. Hyperlipidemia in patients with chronic renal disease. Am J Kidney 1998; Dis32:S $142-56$.

11. Nolan CR; Anderson RJ: Hospital- acquired acute renal filure. Jam Soc Nephrol 1998; 9:710-8.
12. Hricik DE; Chung Park M; Sedor JR : Glomerulonephritis. N Engl J Med. 1998; 339:888.

Address of Correspondence: Shrawan Kumar Yadav, Lecturer, Department of Biochemistry

Nobel Medical College, Biratnagar E-mail: Shrawanyadav36@yahoo.co.in 